\title{
Carcinoma of the Lacrimal Gland Clinical Distant Metastasis TNM Finding v7
}

National Cancer Institute

\section{Source}

National Cancer Institute. Carcinoma of the Lacrimal Gland Clinical Distant Metastasis

TNM Finding v7. NCI Thesaurus. Code C88805.

A clinical finding about one or more characteristics of carcinoma of the lacrimal gland, following the rules of the TNM AJCC V7 classification system as they pertain to distant metastases. 